\title{
Numerical analysis of glued laminated timber beams reinforced by Vectran fibers
}

\author{
Análise numérica de vigas de madeira laminada colada \\ reforçadas com fibras de Vectran
}

\author{
Nilson Tadeu Mascia \\ Carlos Augusto Abade Bertoline \\ Cilmar Donizeti Baságlia \\ Bruno Fazendeiro Donadon
}

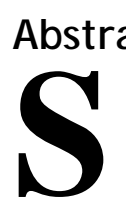

ome factors, such as environmental actions and load increases, can cause a necessity to restore a structural element. An efficient method typically used is to reinforce the structure with a high mechanical property's material. In this study, a numerical approach of glued laminated timber beams reinforced with the following synthetic fibers: Vectran ${ }^{\circledR}$, carbon and glass fibers was developed.Vectran ${ }^{\circledR}$ fibers have high performance and are employed in various areas, but not yet as a structural reinforcement. The beam models were designed on Ansys software-version 12 and the results were analyzed regarding the maximum stresses and displacements. When compared to unreinforced beam, the fiber reinforcement absorbed a great part of the acting stresses, reducing the tensile stress and the displacement maximum values. Considering mechanical properties and the material cost, Vectran ${ }^{\circledR}$ fiber is an interesting alternative for structural reinforcement, fitting its mechanical performance at an intermediate level between carbon fiber and glass fiber.

Keywords: Glued laminated timber. Structural reinforcement. Synthetic fibers. Vectran.

Nilson Tadeu Mascia Universidade Estadual de Campinas Campinas - SP - Brasil

Carlos Augusto Abade Bertoline Universidade Estadual de Campinas Campinas - SP - Brasil

Cilmar Donizeti Baságlia Universidade Estadual de Campinas Campinas - SP - Brasil

Bruno Fazendeiro Donadon Universidade Estadual de Campinas Campinas - SP - Brasil

Recebido em 12/06/16 Aceito em 13/09/17

\section{Resumo}

Alguns fatores, tais como ações ambientais e aumento de carga, podem causar a necessidade de restaurar um elemento estrutural. Um método eficiente tipicamente utilizado é reforçar a estrutura com um material que apresente altas propriedades mecânicas. Neste estudo foi desenvolvida uma abordagem numérica de vigas de madeira laminada colada reforçadas com as seguintes fibras sintéticas: Vectran ${ }^{\circledR}$, carbono e vidro. As fibras de Vectran ${ }^{\circledR}$ têm alto desempenho e são empregadas em várias áreas, mas ainda não como reforço estrutural. Os modelos das vigas foram desenvolvidos no software Ansys versão 12, e os resultados foram analisados considerando-se as máximas tensões e os deslocamentos. Quando comparado com vigas sem reforço, o reforço de fibra absorveu grande parte das tensões atuantes e reduziu os valores máximos de tensão de tração e de deslocamento.

Considerando-se as propriedades mecânicas e o custo do material, a fibra de Vectran ${ }^{\circledR}$ é uma alternativa interessante para reforço estrutural, estando seu desempenho mecânico em um nível intermediário entre a fibra de carbono e a fibra de vidro.

Palavras-chave: Madeira laminada colada. Reforço estrutural. Fibras sintéticas. Vectran $^{\circledR}$. 


\section{Introduction}

Historically, wood and wood-based products have been extensively used as engineering material for structural purposes for a long time. However, due to the constant development of new technologies, a new range of possibilities on how to design and build timber structures is available nowadays. New systems such as Medium Density Fiberboard MDF, Oriented Strand Board - OSB, Glued Laminated Timber - Glulam and more recently Cross Laminated Timber - CLT are currently used and allow the execution of more efficient structures.

The production of Glued Laminated Timber, consisting of the association of gluing and laminating wood techniques, started when high resistance adhesives had been produced, Wood Handbook (2010). The higher resistance layers are positioned at the exterior portions of the beam, whereas lower quality layers are positioned closer to the neutral axis, resulting in an increase of strength and stiffness of structural elements, Thelandersson and Larsen (2003).

Using Glulam, it is possible to manufacture structural elements of any sorts of shapes and dimensions. Furthermore, the production process and the smaller dimensions of the layers compared to equivalent solid wood pieces reduce the wood's natural imperfections, such as knots, pitch and small cracks, resulting in a more homogeneous material with better strength and stiffness properties

As any kind of structure, timber structures are subjected to load changes, purpose changes, chemical and biological agent's interaction and many other variables that may cause the need to restore the initial material properties. This necessity to maintain or even increase structural capability shows the importance of structural repairs and reinforcement on timber structures.

There are mainly two ways to rehabilitate timber structures, which are: the substitution of affected elements and the addition of other materials that can complement the mechanical capacity of the timber element. The first option faces limitations such as the unavailability or incompatibility of proper timber elements or similar wood species, high costs and environmental aggression. Therefore, the second alternative becomes very interesting, involving the use of synthetic fibers, for example: glass (FIORELLI; DIAS, 2011) carbon basalt (GARCÍA; ESCAMILLA; GARCÍA, 2013) and natural fibers, curauá (SILVA; AQUINO, 2008) or sisal (MASCIA; MAYER; MORAES, 2014), that are incorporated into the original timber structure. This association results on a high performance composite system. For instance, Raftery and Rodd
(2015) developing a numerical and experimental research on wood laminated beams reinforced with glass fibers bonded using the phenol resorcinol formaldehyde adhesive noted that slip at the fiber reinforce polymer-wood interface, bonded with an adhesive is negligible. In general, in these systems are applied epoxy and polyurethane adhesives, according to Pizzo and Smedley (2015).

It is worth to be mentioned that the use of fiber reinforcement in timber beams, manufactured with low-resistance class wood species, as for instance Pinus caribea (the ultimate compression strength is 25 MPa, NBR 7190 (ABNT, 1997) would be considerably enhanced.

In this context, this paper presents a numerical analysis of glued laminated timber beams reinforced with synthetic fiber using Ansys software-version 12 (SWANSON..., 2009), focusing on the gain of resistance, displacements and normal stress distribution. In this study, it is taken into consideration Vectran ${ }^{\circledR}$ fibers, Kuraray American (2010), which are still not commonly applied as a civil engineering reinforcement material, and carbon and glass fibers, which are typical fibers employed as structural reinforcement, also considered in this work for comparison reasons.

\section{Composite systems}

The combination of two or more materials on a macroscopic scale to form a new useful material is defined as a composite material. According to Jones (1999), a well-designed composite system exhibits the best quality of their material components and presents qualities that neither component demonstrates individually for performing the same structural purpose. Compared to the constituting materials, some of the physical and mechanical, such as strength, stiffness, corrosion resistance, wear resistance and weight properties can be improved.

Jones (1999) also Bodig and Jones (1982) stated that there are three major groups of existing composite materials, which are fibrous: composite, laminated composite and particulate composite materials. Yet that it is possible to obtain a new material from a combination of two or more of these groups.

Glulam, which consists of various layers with different mechanical properties among each other bonded together by a high strength adhesive, is an example of a laminated composite material. On the other hand, even though synthetic fibers present high modulus of elasticity, strength and toughness, 
they cannot be considered structural material by themselves. What becomes a structural material is the association between the fibers and a matrix material (usually based on an epoxy resin), resulting in a fibrous composite material. In this composite, the fibers will determine strength, stiffness, and the matrix material guaranteeing the main mechanical directions, the stress distribution and the structural integrity of the composite system.

Therefore, Glulam reinforced with synthetic fiber is a combination of both laminated and fibrous composite materials. Also it is important to mention that the adhesive used to apply the reinforcement layer is also a significant component of the resulting composite system, as the adhesive joint can become a critical point due to appropriate adhesion between the reinforcement layer and the timber layer, Neubauerová (2012).

Yet it is important to note that timber structures present brittle failure in tension. However, when properly reinforced this mechanical behavior changes and a ductile failure mode can be verified. Thus, the Glulam structures reinforced with fibers present excessive displacements before the failure occurs, considering that the reinforcement plays a major role to the behavior of the Glulam beam, Dagher (1999) and Tsalkatidis (2014).

\section{Vectran ${ }^{\circledR}$ fibers}

Vectran $^{\circledR}$ is a high-performance multifilament yarn spun from liquid crystal polymer (LCP) and the only commercially available melt spun LCP fiber in the world. Considering a pound-to-pound comparison, this fiber is five times stronger than steel and ten times stronger than aluminum. Some of the properties that characterize it are: high strength and modulus of elasticity, high creep, cut, impact and abrasion resistance, low coefficient of thermal expansion and properties retention at high and low temperatures, Kuraray American (2010).

Vectran ${ }^{\circledR}$ fibers have not largely used yet for civil engineering purposes. However, they currently represent successful application in other demanding areas, since these fibers offer a combination and balance of properties that are unmatched by other high performance fibers. These fibers are used in aerospace and military areas, ocean exploration and development, safety materials, industrial applications, protective apparel, cables and composites, demonstrating their high mechanical performance.

Considering their uses in the international scenario, aramid fiber and ultra-high molecular weight polyethylene (HMPE) fiber are some of Vectran ${ }^{\circledR}$ fiber alternatives. However, Vectran ${ }^{\circledR}$ fibers differ from these alternatives due to their unique thermal, chemical, tensile and resistance properties. In addition, during the LCP extrusion the molecular domains are oriented parallel to fiber axis, resulting in a material with excellent tensile property. On the other hand, the conventional polyesters possess random and flexible molecular chains, which means that the fibers spun from these materials must be further oriented to obtain higher tensile properties, Kuraray American (2010).

Figure 1 illustrates this molecular chain comparison and LCP's high orientation.

\section{Figure 1 - Schematic of molecular chain structure of fiber}

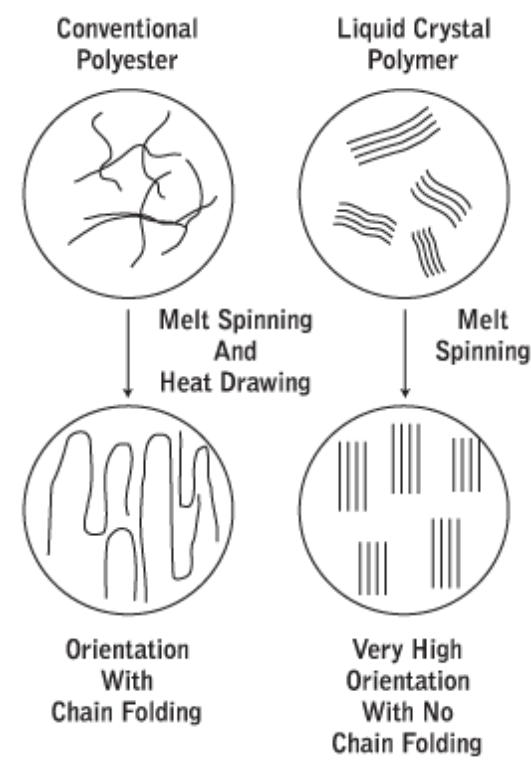

Source: Kuraray American (2010). 
Table 1 lists some physical and mechanical properties in order to establish an average comparison between Vectran ${ }^{\circledR}$ fiber and other engineering materials.

\section{Methodology}

This section deals with a numerical modeling and an analysis of timber beams with various dimensions using Ansys Software (SWANSON..., 2009). The mechanical behaviors of both the unreinforced and the fiber reinforced glued laminated timber beams were analyzed in terms of the maximum displacements and the stress distribution for each case studied.

In this analysis, the wood-adhesive and adhesivefiber connections were considered homogeneous and rigid and the effects caused by the bonding adhesive were not taken into account. Furthermore, the mechanical properties' average values of the timber layers were not considered as well. Thus, the timber portion of the composite was modeled as only a solid piece. Yet the connections between timber layers were also assumed as a rigid and homogeneous connection.

The consideration of the linear elastic behavior modeling of fiber on the reinforced Glulam produces adequate results, in particular, when this analysis is related to the tension side of a timber beam, Bertoline et al. (2015). This modeling considered a structural orthotropic linear elastic behavior for every material too.

Three typical and generic cross section models were adopted to the numerical analysis, as illustrated by Figures 2, 3 and 4.

Based on these models and typical geometries, shown by Figures 2 to 4, Table 2 to 4 present the specimen identification, the geometrical information and the fiber types.

Table 1 - Physical and mechanical properties of engineering materials

\begin{tabular}{l|c|c|c|c|c}
\hline \multicolumn{1}{c|}{ Material } & $\begin{array}{c}\text { Density } \\
\left(\mathbf{g} / \mathbf{c m}^{\mathbf{3}}\right)\end{array}$ & $\begin{array}{c}\text { Tensile } \\
\text { Strength (GPa) }\end{array}$ & $\begin{array}{c}\text { Specific } \\
\text { Strength (1) }\end{array}$ & $\begin{array}{c}\text { Tensile } \\
\text { Modulus (GPa) }\end{array}$ & $\begin{array}{c}\text { Specific } \\
\text { Modulus (2) }\end{array}$ \\
\hline Vectran ${ }^{\circledR}$ NT & 1.4 & 1.1 & 79 & 52 & 3700 \\
Vectran ${ }^{\circledR}$ HT & 1.4 & 3.2 & 229 & 75 & 5300 \\
Vectran ${ }^{\circledR}$ UM & 1.4 & 3.0 & 215 & 103 & 7400 \\
Stainless Steel & 7.9 & 2.0 & 26 & 210 & 2700 \\
Aluminum & 2.8 & 0.6 & 22 & 70 & 2600 \\
E-Glass & 2.6 & 3.4 & 130 & 72 & 2800 \\
\hline
\end{tabular}

Note: (1) - Specific strength = strength/ density divided by force of gravity for SI units; and (2) - Specific modulus = modulus / density divided by force of gravity for SI units.

Figure 2 - Typical geometry 1 -fiber reinforcement placed below the bottom layer

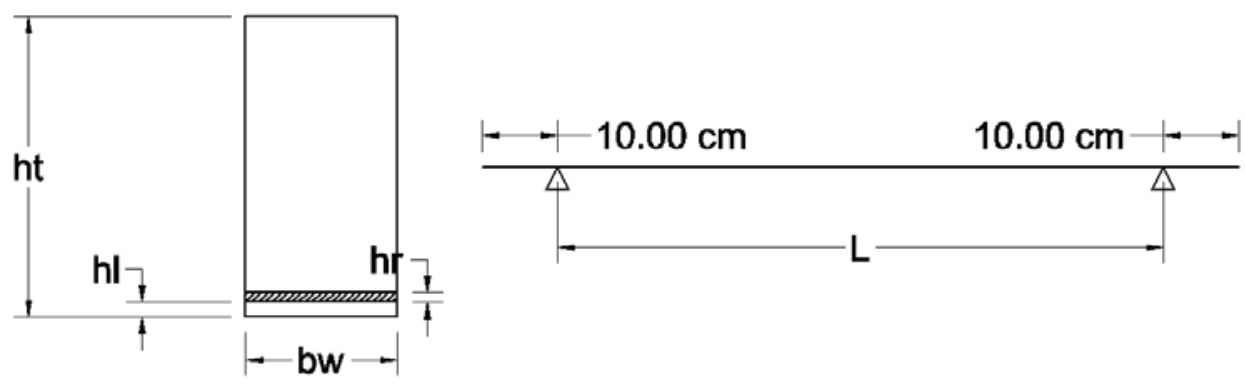

Figure 3 - Typical geometry 2 - fiber reinforcement placed on the bottom surface
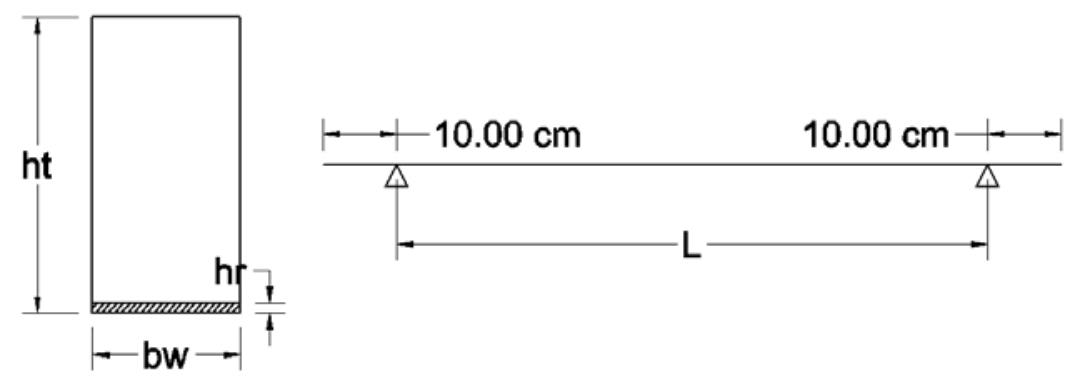
Figure 4 - Typical geometry 3 - unreinforced timber beams
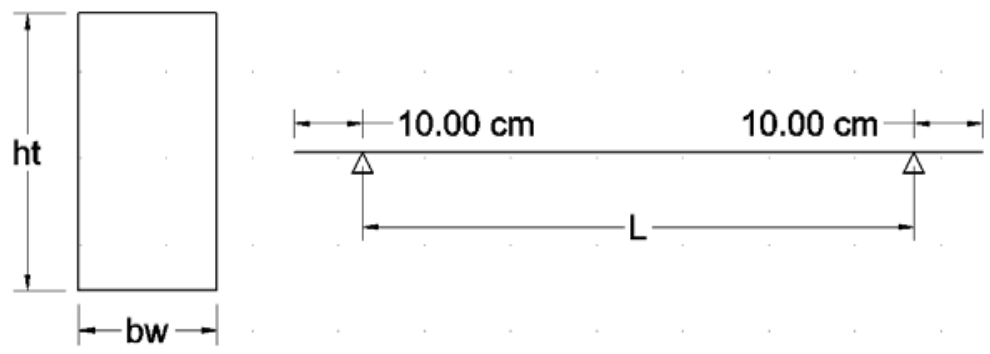

Table 2 - Model information: $\mathbf{3 0 0}-\mathbf{c m}$ length beams (Dimensions in $\mathbf{c m}$ )

\begin{tabular}{c|c|c|c|c|c|c|c}
\hline Model & Typical Geometry & $\mathbf{L}$ & $\mathbf{b}_{\mathbf{w}}$ & $\mathbf{h}_{\mathbf{r}}$ & $\mathbf{h}_{\mathbf{l}}$ & $\mathbf{h}_{\mathbf{t}}$ & Fiber Type \\
\hline VT-5 & 3 & 300 & 10.00 & -------- & -------- & 30.00 & No fiber \\
VT-6A & 1 & 300 & 10.00 & 0.25 & 3.00 & 30.25 & Vectran $^{\circledR}$ \\
VT-6B & 1 & 300 & 0,00 & 0.25 & 3.00 & 30.25 & Glass \\
VT-6C & 1 & 300 & 10.00 & 0.25 & 3.00 & 30.25 & Carbon \\
VT-6D & 2 & 300 & 10.00 & 0.25 & 3.00 & 30.25 & Vectran $^{\circledR}$ \\
VT-6E & 2 & 300 & 10.00 & 0.25 & 3.00 & 30.25 & Glass \\
VT-6F & 2 & 300 & 10.00 & 0.25 & 3.00 & 30.25 & Carbon \\
VT-7A & 1 & 300 & 10.00 & 0.50 & 3.00 & 30.50 & Vectran $^{\circledR}$ \\
VT-7B & 1 & 300 & 10.00 & 0.50 & 3.00 & 30.50 & Glass \\
VT-7C & 1 & 300 & 10.00 & 0.50 & 3.00 & 30.50 & Carbon \\
VT-7D & 2 & 300 & 10.00 & 0.50 & 3.00 & 30.50 & Vectran $^{\circledR}$ \\
VT-7E & 2 & 300 & 10.00 & 0.50 & 3.00 & 30.50 & Glass \\
VT-7F & 2 & 300 & 10.00 & 0.50 & 3.00 & 30.50 & Carbon \\
VT-8A & 1 & 300 & 10.00 & 0.75 & 3.00 & 30.75 & Vectran $^{\circledR}$ \\
VT-8B & 1 & 300 & 10.00 & 0.75 & 3.00 & 30.75 & Glass \\
VT-8C & 1 & 300 & 10.00 & 0.75 & 3.00 & 30.75 & Carbon \\
VT-8D & 2 & 300 & 10.00 & 0.75 & 3.00 & 30.75 & Vectran $^{\circledR}$ \\
VT-8E & 2 & 300 & 10.00 & 0.75 & 3.00 & 30.75 & Glass \\
VT-8F & 2 & 300 & 10.00 & 0.75 & 3.00 & 30.75 & Carbon \\
\hline
\end{tabular}

Table 3 - Model information: $\mathbf{4 0 0}-\mathbf{c m}$ length beams (Dimensions in $\mathbf{c m}$ )

\begin{tabular}{|c|c|c|c|c|c|c|c|}
\hline Model & Typical Geometry & $\mathbf{L}$ & $\mathbf{b}_{\mathrm{w}}$ & $\mathbf{h}_{\mathbf{r}}$ & $\mathbf{h}_{\mathbf{l}}$ & $\mathbf{h}_{t}$ & Fiber Type \\
\hline VT-1 & 3 & 400 & 20.00 & ----------- & ----------- & 40.00 & No fiber \\
\hline VT-2A & 1 & 400 & 20.00 & 0.75 & 2.00 & 40.75 & Vectran ${ }^{\circledR}$ \\
\hline VT-2B & 1 & 400 & 20.00 & 0.75 & 2.00 & 40.75 & Glass \\
\hline VT-2C & 1 & 400 & 20.00 & 0.75 & 2.00 & 40.75 & Carbon \\
\hline VT-2D & 2 & 400 & 20.00 & 0.75 & 2.00 & 40.75 & Vectran $^{\circledR}$ \\
\hline VT-2E & 2 & 400 & 20.00 & 0.75 & 2.00 & 40.75 & Glass \\
\hline VT-2F & 2 & 400 & 20.00 & 0.75 & 2.00 & 40.75 & Carbon \\
\hline VT-3A & 1 & 400 & 20.00 & 1.00 & 2.00 & 41.00 & Vectran ${ }^{\circledR}$ \\
\hline VT-3B & 1 & 400 & 20.00 & 1.00 & 2.00 & 41.00 & Glass \\
\hline VT-3C & 1 & 400 & 20.00 & 1.00 & 2.00 & 41.00 & Carbon \\
\hline VT-3D & 2 & 400 & 20.00 & 1.00 & 2.00 & 41.00 & Vectran $^{\circledR}$ \\
\hline VT-3E & 2 & 400 & 20.00 & 1.00 & 2.00 & 41.00 & Glass \\
\hline VT-3F & 2 & 400 & 20.00 & 1.00 & 2.00 & 41.00 & Carbon \\
\hline VT-4A & 1 & 400 & 20.00 & 1.25 & 2.00 & 41.25 & Vectran ${ }^{\circledR}$ \\
\hline VT-4B & 1 & 400 & 20.00 & 1.25 & 2.00 & 41.25 & Glass \\
\hline VT-4C & 1 & 400 & 20.00 & 1.25 & 2.00 & 41.25 & Carbon \\
\hline VT-4D & 2 & 400 & 20.00 & 1.25 & 2.00 & 41.25 & Vectran $^{\circledR}$ \\
\hline VT-4E & 2 & 400 & 20.00 & 1.25 & 2.00 & 41.25 & Glass \\
\hline VT-4F & 2 & 400 & 20.00 & 1.25 & 2.00 & 41.25 & Carbon \\
\hline
\end{tabular}


Table 4 - Model information: $600-\mathbf{c m}$ length beams (Dimensions in $\mathbf{c m}$ )

\begin{tabular}{|c|c|c|c|c|c|c|c|}
\hline Model & Typical Geometry & $\mathbf{L}$ & $\mathbf{b}_{\mathrm{w}}$ & $\mathbf{h}_{\mathbf{r}}$ & $h_{\mathbf{l}}$ & $\mathbf{h}_{\mathbf{t}}$ & Fiber Type \\
\hline VT-9 & 3 & 600 & 25.00 & ---------- & ---------- & 60.00 & No fiber \\
\hline VT-10A & 1 & 600 & 25.00 & 1.00 & 3.00 & 61.00 & Vectran $^{\circledR}$ \\
\hline VT-10B & 1 & 600 & 25.00 & 1.00 & 3.00 & 61.00 & Glass \\
\hline VT-10C & 1 & 600 & 25.00 & 1.00 & 3.00 & 61.00 & Carbon \\
\hline VT-10D & 2 & 600 & 25.00 & 1.00 & 3.00 & 61.00 & Vectran $^{\circledR}$ \\
\hline VT-10E & 2 & 600 & 25.00 & 1.00 & 3.00 & 61.00 & Glass \\
\hline VT-10F & 2 & 600 & 25.00 & 1.00 & 3.00 & 61.00 & Carbon \\
\hline VT-11A & 1 & 600 & 25.00 & 1.25 & 3.00 & 61.25 & Vectran $^{\circledR}$ \\
\hline VT-11B & 1 & 600 & 25.00 & 1.25 & 3.00 & 61.25 & Glass \\
\hline VT-11C & 1 & 600 & 25.00 & 1.25 & 3.00 & 61.25 & Carbon \\
\hline VT-11D & 2 & 600 & 25.00 & 1.25 & 3.00 & 61.25 & Vectran $^{\circledR}$ \\
\hline VT-11E & 2 & 600 & 25.00 & 1.25 & 3.00 & 61.25 & Glass \\
\hline VT-11F & 2 & 600 & 25.00 & 1.25 & 3.00 & 61.25 & Carbon \\
\hline VT-12A & 1 & 600 & 25.00 & 1.50 & 3.00 & 61.50 & Vectran $^{\circledR}$ \\
\hline VT-12B & 1 & 600 & 25.00 & 1.50 & 3.00 & 61.50 & Glass \\
\hline VT-12C & 1 & 600 & 25.00 & 1.50 & 3.00 & 61.50 & Carbon \\
\hline VT-12D & 2 & 600 & 25.00 & 1.50 & 3.00 & 61.50 & Vectran $^{\circledR}$ \\
\hline VT-12E & 2 & 600 & 25.00 & 1.50 & 3.00 & 61.50 & Glass \\
\hline VT-12F & 2 & 600 & 25.00 & 1.50 & 3.00 & 61.50 & Carbon \\
\hline
\end{tabular}

The properties needed for modeling are presented in Table 5 (NBR 7190, ABNT, 1997) and Table 6 (BERTOLINE et al., 2015), in which, $E_{\mathrm{i}}$ represents the modulus of elasticity in each direction; $G_{i j}$ is the transversal modulus of rigidity in each plane, and $\mathrm{v}_{\mathrm{ij}}$ is the Poisson's ratio in each plane.

By taking into account Tables 2 to 6 the numerical analysis was performed. The results were obtained via Ansys (SWANSON..., 2009) finite element simulations, involving beam discretizations into Solid Brick 8 Node 45 elements. To define the discretization and the number of finite elements a previous convergence analysis was performed. At this stage, it is worth mentioning that the local coordinate system for each element was aligned with the beam's global coordinate system $(\mathrm{x}, \mathrm{y}, \mathrm{z})$ located at the top surface of the cross section on the left of the beam as Figure 5 shows. The x-axis is related to the length, whereas the $y$-axis and z-axis are vertical and horizontal directions of the cross section of the beam.

It was adopted to define the size and the number of finite elements the following relations: $\mathrm{x}$-direction: $\mathrm{X}_{\text {elem }}=\mathrm{L} / 100 ; \mathrm{y}$-direction: $\mathrm{Y}_{\text {elem }}=\mathrm{b}_{\mathrm{w}} / 6$ and $\mathrm{z}$ direction: $Z_{\text {elem }}=h_{t} / 10$, where $L$ is beam length, $b_{w}$ is width of the beam cross section beam and $h$ is the height, according to Zienkiewicz and Taylor (2000). In the numerical analyses 7488 elements were required, making a total of 9555 nodes (i.e., 28665 degrees of freedom), comprising a processing time less than 2 minutes. It is adopted smaller finite elements for the fiber layer due to the height of layer is smaller than the height of the cross section of the beam. Figure 5 illustrates this typical mesh for the beams.

The analyzed beams were considered simply supported with a simulated concentrated load applied at the mid-span as Figure 6 shows. Both the load and constraint properties were distributed in the nodes along the width of the beams. It is interesting to cite Cunha and Souza Junior (2004) that used successfully the following Ansys' elements: Solid 46 and Shell 99 to investigate numerically timber laminated beams reinforced with carbon fibers, bonded by epoxy resin, in terms of normal and shear stresses, and also Bertoline (2015), which results are used in this piece of research.

In this model a $2 / 3$ beam's failure load of the unreinforced beam was considered to establish a pattern for the numerical results. The Brazilian Code for timber structures, NBR 7190 (ABNT, 1997), establishes that at the level of around $2 / 3$ of the failure load the compression and the tension still in the linear pattern. Thus, in this study for each analyzed beam was applied an incremental load in order to reach the $2 / 3$ - failure load of an unreinforced beam, which presents the same crosssection dimensions of the reinforced beams. Thus, the failure load of the unreinforced beam was obtained considering a tensile failure stress 3.54 $\mathrm{kN} / \mathrm{cm}^{2}$, which corresponds to the failure stress according to the NBR 7190 (ABNT, 1997).

This approach involved a three-dimensional analysis, in which the load was applied on the nodes at the mid-span and the reaction loads were applied on lateral supports nodes. 
Regarding the displacements, the horizontal and vertical ones were restricted at the $10 \mathrm{~cm}$ from the beam edges. In addition, in order to avoid singularities in the model a horizontal restriction at a mid-span node was considered.
The effects of the use of synthetic fiber reinforcement are expressed in terms of maximum tensile stress on timber reduction and final displacement reduction. This reduction is obtained from the comparison with an unreinforced timber beam, with the same cross section dimension.

Table 5 - Properties for Pinus caribea (Unit kN. cm-2 unless for Poisson's ratios)

\begin{tabular}{c|c|c|c|c|c|c|c|c}
\hline $\mathbf{E}_{\mathbf{x}}$ & $\mathbf{E}_{\mathbf{y}}$ & $\mathbf{E}_{\mathbf{z}}$ & $\mathbf{G}_{\mathbf{x y}}$ & $\mathbf{G}_{\mathbf{y z}}$ & $\mathbf{G}_{\mathbf{x z}}$ & $\mathbf{v}_{\mathbf{x y}}$ & $\mathbf{v}_{\mathbf{x z}}$ & $\mathbf{v}_{\mathbf{x z}}$ \\
\hline 547.10 & 73.76 & 104.94 & 30.70 & 11.63 & 54.26 & 0.3346 & 0.4509 & 0.3701 \\
\hline
\end{tabular}

Table 6 - Elastic properties of fibers (Unit kN. $\mathbf{c m}^{-2}$ unless for Poisson's ratios)

\begin{tabular}{l|c|c|c|c|c|c|c}
\hline \multicolumn{1}{c|}{ Fibers } & $\mathbf{E}_{\mathbf{x}}$ & $\mathbf{E}_{\mathbf{y}}$ & $\mathbf{E}_{\mathbf{z}}$ & $\mathbf{G}_{\mathbf{x y}}$ & $\mathbf{G}_{\mathbf{y z}}$ & $\mathbf{G}_{\mathbf{x z}}$ & $\mathbf{v}_{\mathbf{x y}}=\mathbf{v}_{\mathbf{x z}}=\mathbf{v}_{\mathbf{x z}}$ \\
\hline EGlass & 7400 & 7400 & 7400 & 2960 & 2960 & 2960 & 0.25 \\
HRCarbon & 23000 & 23000 & 23000 & 8846 & 8846 & 8846 & 0.30 \\
Vectran $^{\circledR} \mathrm{UM}$ & 10300 & 10300 & 10300 & 3961 & 3961 & 3961 & 0.30 \\
\hline
\end{tabular}

Figure 5 - The mesh of finite elements for the adopted beam

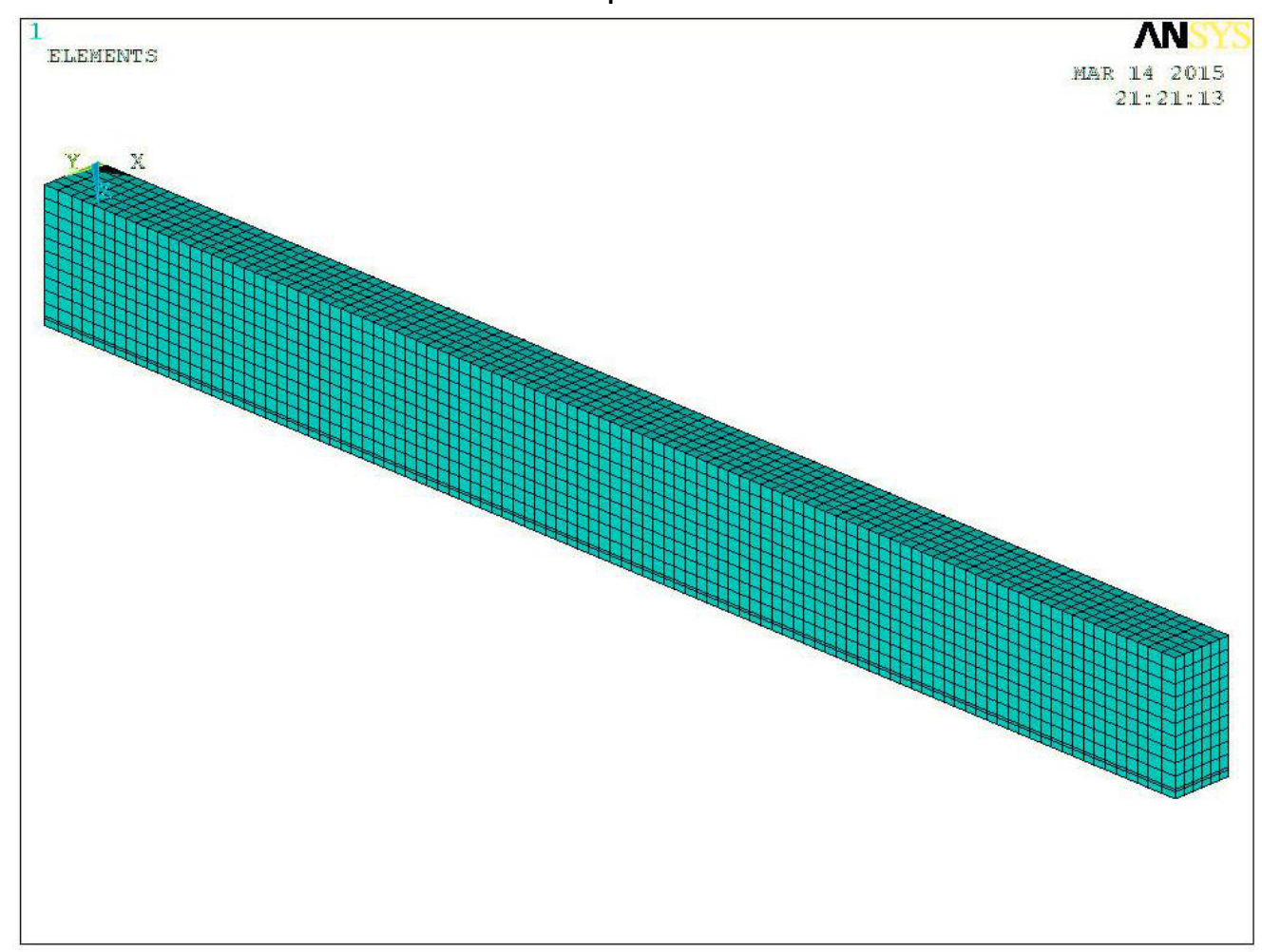


Figure 6 - Beam with the load applied at the mid-span and reaction forces at the supports

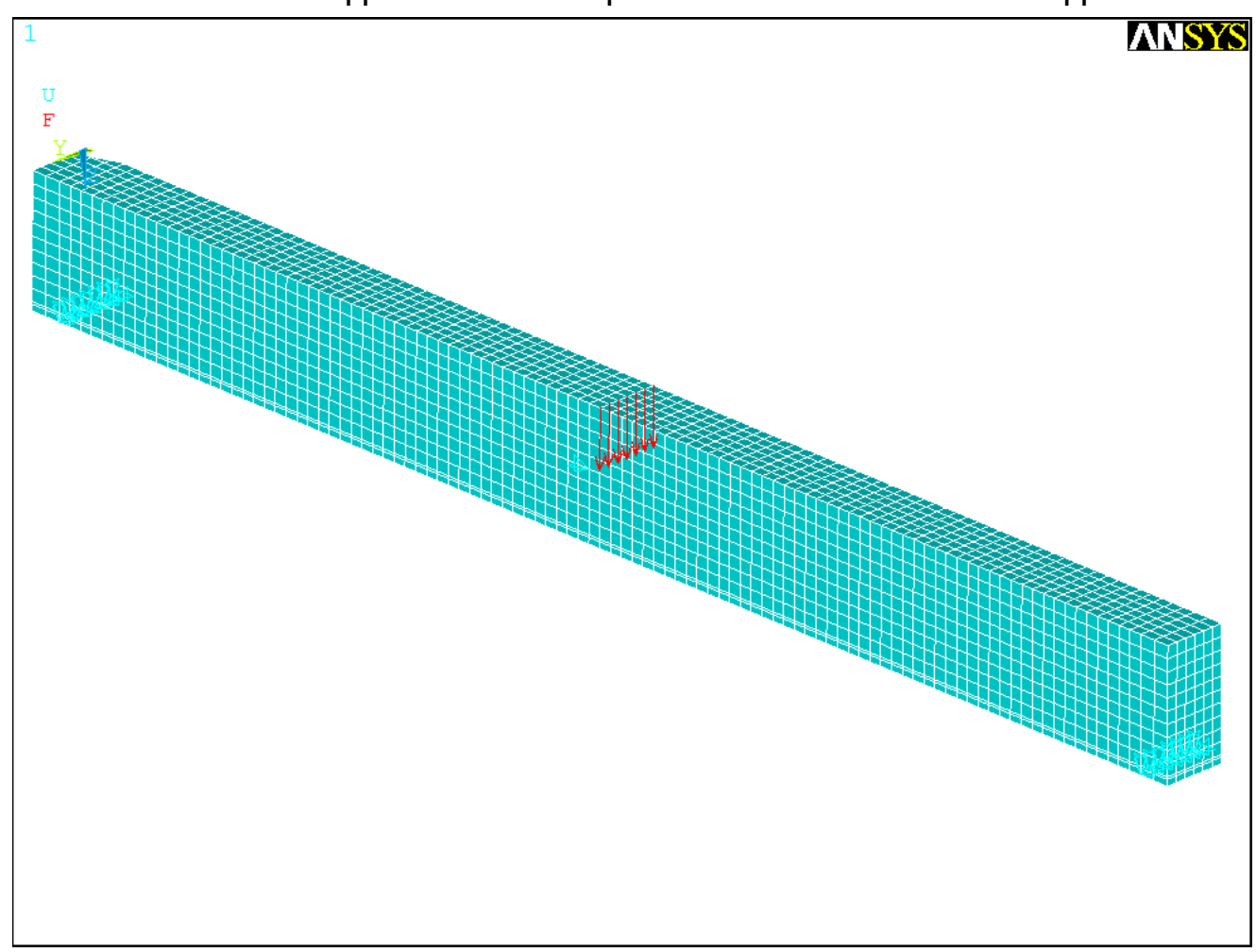

\section{Result analysis and discussion}

Table 7 presents the obtained numerical results for each beam, i.e., the $2 / 3$ failure load and the consequence maximum tensile stresses in timber parts and fibers, as well as the maximum displacements. Furthermore, this table shows the reduction in the maximum stress and displacements take into consideration the unreinforced and reinforced beams for each type of beam considered in this study.

From the obtained results, shown in Table 7 , the employ of Vectran ${ }^{\circledR}$ fibers implied an average reduction of $56 \%$ the maximum tensile stress on timber, whereas the use of glass fiber and the carbon fiber in $49 \%$ and $72.60 \%$ respectively. Considering the maximum displacements of reinforced beams, an average reduction of $36.61 \%$ was observed when Vectran ${ }^{\circledR}$ fibers were used, and $31.81 \%$ for glass fibers and $46.89 \%$ for the carbon fiber.

It can be noted from the results listed in Table 7 that the average maximum stress reduction in timber portion considering the carbon fiber was $16.6 \%$ greater than Vectran ${ }^{\circledR}$ fiber and $23.6 \%$ greater for the glass fiber. In addition, the maximum stress reduction provided by the carbon fibers can be reached by using of the Vectran ${ }^{\circledR}$ fibers, just applying an additional thicker reinforcement layer.
To illustrate the stress distribution results the following figures are presented: Figure 7 displays an unreinforced timber beam (typical geometry 3), Figure 8 shows the reinforced timber beam (typical geometry 1) and Figure 9 illustrates the fiber portion.

As expected, the reinforcement layer absorbs a great portion of the acting stresses, which results in a reduction of the maximum tensile stress acting in the timber portion of the composite. Another issue to be considered is related to the high concentration of compressive stresses that were close to the point where the load was applied, resulting in a crushing area. These high compressive stresses are highlighted by Schober et al. (2015) for FRP (Fiber Reinforced Polymer) reinforcements. In general, two failure modes are to be considered: the first, the failure of the timber portion is due to the tensile stress, while the compression portion remains with linear elastic behavior and the second mode, the failure in timber by the tensile stress and the plastic behavior is observed in the compressive zone, according to Bertoline et al. (2015) based on the theoretical approach of Romani and Blaß (2001).

Since there is a significant difference in the maximum stresses of the timber portion and the fiber portion, when a reinforced beam is analyzed, the stress distribution in timber appears to be almost uniform, which not to correspond the real mechanical behavior. 
Table 7 - Numerical analysis results of the analyzed beams

\begin{tabular}{|c|c|c|c|c|c|c|}
\hline Beams & $\begin{array}{c}\text { Load } \\
(k N)\end{array}$ & $\begin{array}{l}\text { Maximum } \\
\text { tensile stress } \\
\text { in timber } \\
(\mathbf{k N . c m}-2)\end{array}$ & $\begin{array}{c}\text { Maximum } \\
\text { tensile stress in } \\
\text { fiber (kN.cm-2) }\end{array}$ & $\begin{array}{l}\text { Maximum beam } \\
\text { displacements } \\
(\mathrm{cm})\end{array}$ & $\begin{array}{l}\text { Reduction in the } \\
\text { maximum stress } \\
\text { in timber }(\%)\end{array}$ & $\begin{array}{c}\text { Reduction in } \\
\text { the maximum } \\
\text { displaciments } \\
(\%)\end{array}$ \\
\hline VT-1 & 119 & 2.250 & -------- & 3.237 & -------- & -------- \\
\hline VT-2A & 119 & 1.103 & 16.88 & 2.129 & 50.97 & 34.23 \\
\hline VT-2B & 119 & 1.281 & 14.35 & 2.287 & 43.06 & 29.35 \\
\hline VT-2C & 119 & 0.722 & 22.69 & 1.783 & 67.92 & 44.92 \\
\hline VT-2D & 119 & 0.843 & 17.33 & 1.981 & 62.54 & 38.80 \\
\hline VT-2E & 119 & 1.027 & 14.96 & 2.150 & 54.34 & 33.58 \\
\hline VT-2F & 119 & 0.467 & 22.52 & 1.627 & 79.24 & 49.74 \\
\hline VT-3A & 119 & 0.965 & 14.50 & 1.983 & 57.11 & 38.74 \\
\hline VT-3B & 119 & 1.138 & 12.58 & 2.136 & 49.44 & 34.01 \\
\hline VT-3C & 119 & 0.620 & 18.84 & 1.672 & 72.42 & 48.35 \\
\hline VT-3D & 119 & 0.684 & 14.70 & 1.831 & 69.59 & 43.44 \\
\hline VT-3E & 119 & 0.858 & 12.95 & 1.991 & 61.88 & 38.49 \\
\hline VT-3F & 119 & 0.354 & 18.52 & 1.517 & 84.25 & 53.14 \\
\hline VT-4A & 119 & 0.865 & 12.816 & 1.873 & 61.53 & 42.14 \\
\hline VT-4B & 119 & 1.030 & 11.264 & 2.018 & 54.23 & 37.66 \\
\hline VT-4C & 119 & 0.554 & 16.382 & 1.592 & 75.38 & 50.82 \\
\hline VT-4D & 119 & 0.569 & 12.871 & 1.720 & 74.72 & 46.86 \\
\hline VT-4E & 119 & 0.729 & 11.484 & 1.870 & 67.58 & 42.23 \\
\hline VT-4F & 119 & 0.277 & 15.973 & 1.441 & 87.68 & 55.48 \\
\hline VT-5 & 49 & 2.468 & -------- & 2.649 & -------- & -------- \\
\hline VT-6A & 49 & 1.792 & 24.211 & 2.165 & 27.39 & 18.27 \\
\hline VT-6B & 49 & 1.937 & 19.098 & 2.262 & 21.54 & 14.61 \\
\hline VT-6C & 49 & 1.381 & 38.771 & 1.888 & 44.04 & 28.73 \\
\hline VT-6D & 49 & 1.437 & 27.885 & 1.974 & 41.79 & 25.48 \\
\hline VT-6E & 49 & 1.631 & 22.636 & 2.103 & 33.92 & 20.61 \\
\hline VT-6F & 49 & 0.949 & 41.572 & 1.638 & 61.57 & 38.17 \\
\hline VT-7A & 49 & 1.449 & 18.683 & 1.907 & 41.30 & 28.01 \\
\hline VT-7B & 49 & 1.623 & 15.498 & 2.024 & 34.24 & 23.59 \\
\hline VT-7C & 49 & 1.038 & 26.460 & 1.631 & 57.93 & 38.43 \\
\hline VT-7D & 49 & 0.998 & 20.268 & 1.669 & 59.55 & 37.00 \\
\hline VT-7E & 49 & 1.204 & 17.356 & 1.810 & 51.22 & 31.67 \\
\hline VT-7F & 49 & 0.568 & 26.787 & 1.366 & 76.99 & 48.43 \\
\hline VT-8A & 49 & 1.242 & 15.420 & 1.743 & 49.69 & 34.20 \\
\hline VT-8B & 49 & 1.417 & 13.168 & 1.860 & 42.60 & 29.78 \\
\hline VT-8C & 49 & 0.872 & 20.699 & 1.495 & 64.69 & 43.56 \\
\hline VT-8D & 49 & 0.750 & 16.142 & 1.493 & 69.60 & 43.64 \\
\hline VT-8E & 49 & 0.941 & 14.222 & 1.625 & 61.89 & 38.66 \\
\hline VT-8F & 49 & 0.388 & 20.323 & 1.235 & 84.26 & 53.38 \\
\hline VT-9 & 217 & 2.187 & ------- & 4.716 & ------- & -------- \\
\hline VT-10A & 217 & 1.292 & 17.408 & 3.189 & 40.92 & 32.38 \\
\hline VT-10B & 217 & 1.302 & 14.662 & 3.420 & 40.47 & 27.48 \\
\hline VT-10C & 217 & 0.746 & 23.803 & 2.669 & 65.88 & 43.41 \\
\hline VT-10D & 217 & 0.885 & 17.956 & 2.975 & 59.55 & 36.92 \\
\hline VT-10E & 217 & 1.067 & 15.375 & 3.224 & 51.23 & 31.64 \\
\hline VT-10F & 217 & 0.503 & 23.731 & 2.436 & 76.99 & 48.35 \\
\hline VT-11A & 217 & 1.022 & 15.553 & 3.021 & 53.28 & 35.94 \\
\hline VT-11B & 217 & 1.193 & 13.318 & 3.250 & 45.44 & 31.09 \\
\hline VT-11C & 217 & 0.663 & 20.611 & 2.534 & 69.69 & 46.27 \\
\hline VT-11D & 217 & 0.762 & 15.888 & 2.800 & 65.17 & 40.63 \\
\hline VT-11E & 217 & 0.938 & 13.828 & 3.044 & 57.12 & 35.45 \\
\hline VT-11F & 217 & 0.412 & 20.384 & 2.304 & 81.16 & 51.15 \\
\hline VT-12A & 217 & 0.938 & 14.107 & 2.885 & 57.13 & 38.83 \\
\hline VT-12B & 217 & 1.105 & 12.235 & 3.109 & 49.47 & 34.08 \\
\hline VT-12C & 217 & 0.602 & 18.323 & 2.431 & 72.46 & 48.45 \\
\hline VT-12D & 217 & 0.665 & 14.300 & 2.662 & 69.60 & 43.55 \\
\hline VT-12E & 217 & 0.834 & 12.598 & 2.897 & 61.89 & 38.57 \\
\hline VT-12F & 217 & 0.344 & 18.006 & 2.204 & 84.26 & 53.27 \\
\hline
\end{tabular}


Figure 7 - Stress distribution on non-reinforced timber beam VT-5 (kN. cm-2)

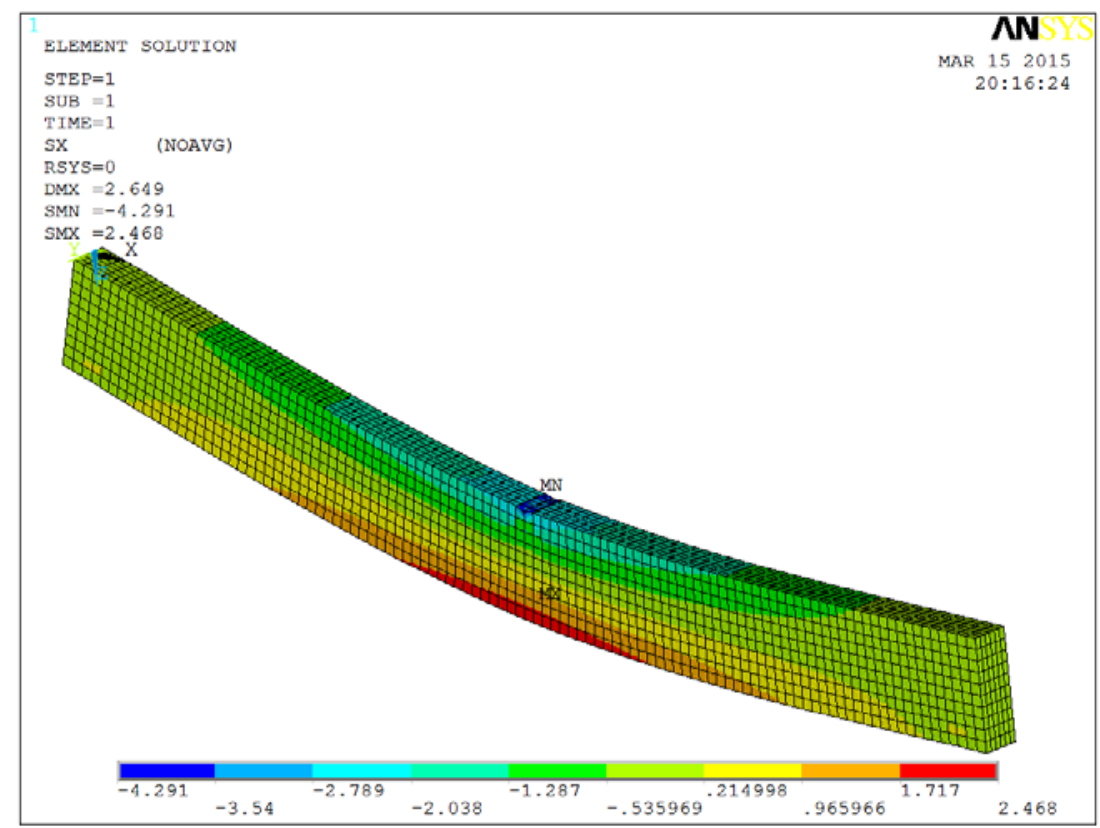

Figure 8 - Stress distribution in the typical geometry 1 reinforced beamVT-6C $\left(\mathrm{kN} . \mathrm{cm}^{-2}\right)$

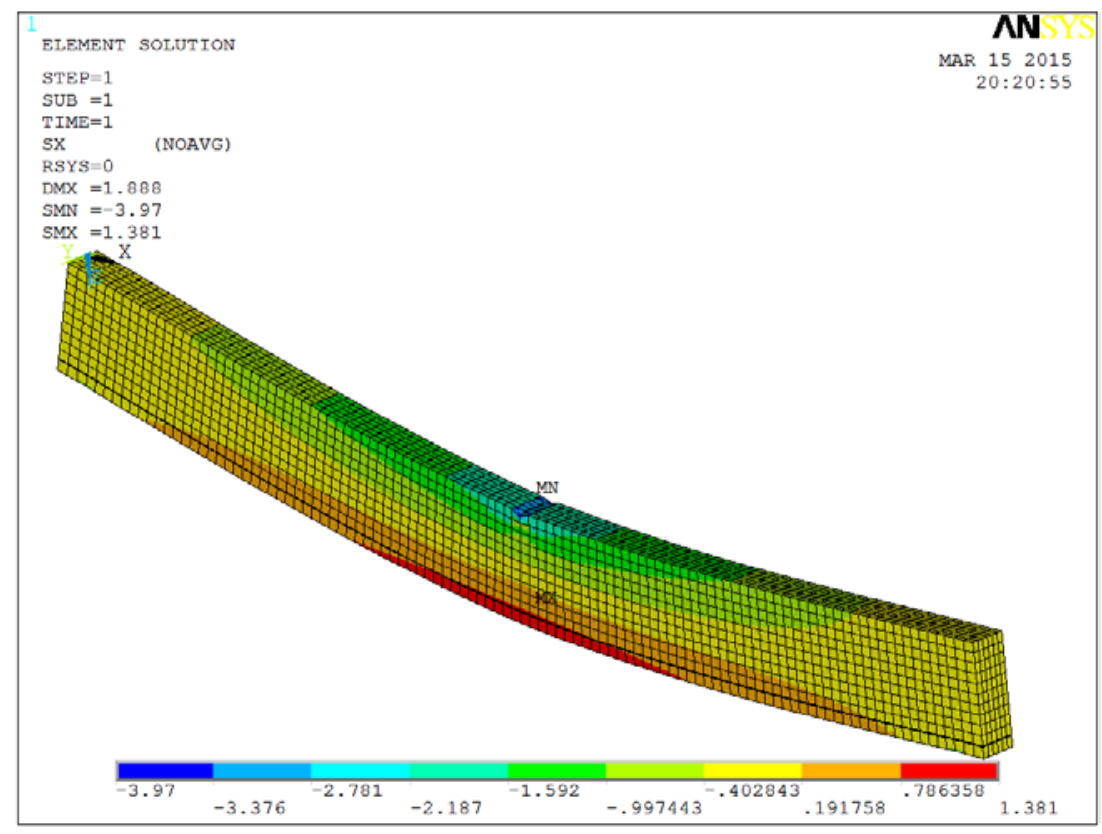


Figure 9 - Stress distribution in the fiber portion of typical geometry 1 reinforced beam VT-6C (kN. $\left.\mathrm{cm}^{-2}\right)$

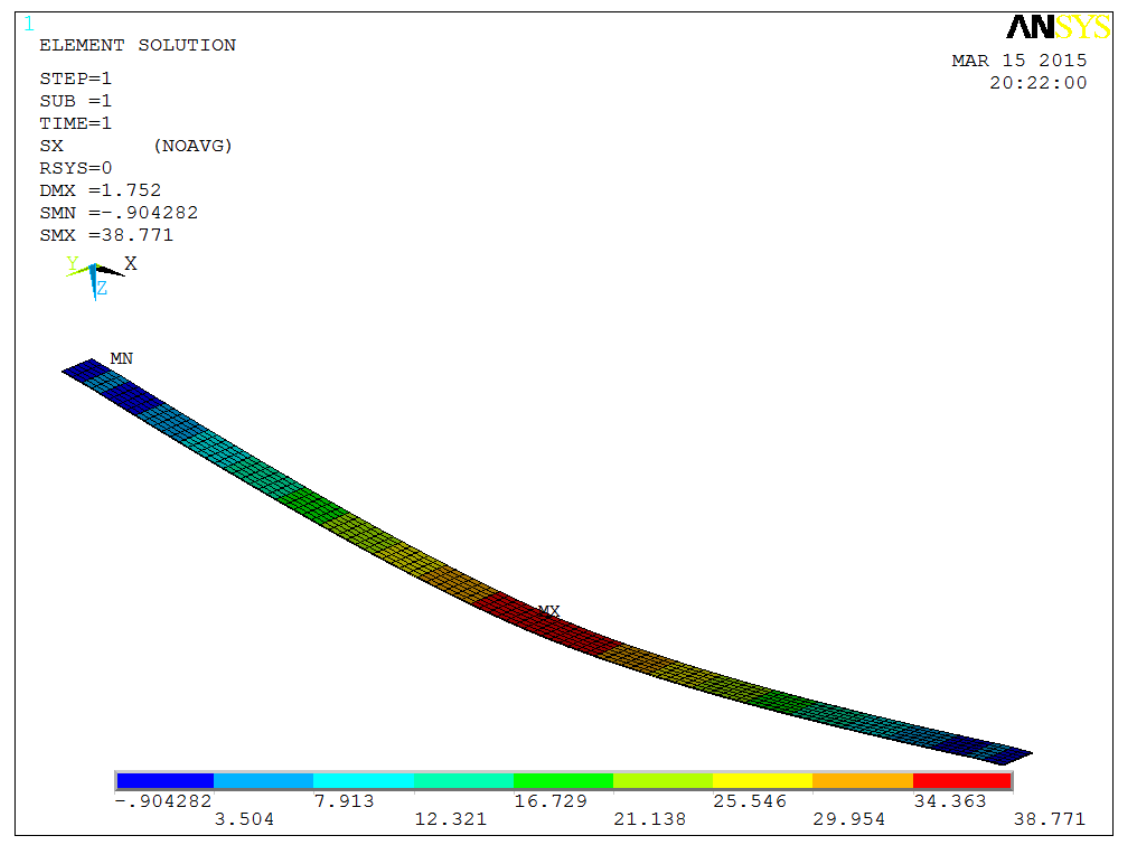

In order to enable a more precise evaluation, the results of the maximum stress in timber portion were summarized in Figures 10 to 12 . These figures were separated according to the beam's dimensions, permitting a better analysis of the fiber reinforcement in the Glulam.

Figures 13 to 15 show the maximum displacement in the beams. From these figures it is possible to infer for the average maximum displacement reduction that: when the carbon fibers was used, this reduction was $10.28 \%$ greater than when Vectran ${ }^{\circledR}$ fibers was used and also $15.08 \%$ greater than when glass fiber.

\section{Conclusions}

This study was addressed to a numerical approach of timber laminated beams reinforced by synthetic fibers. To perform this approach Ansys software (SWANSON..., 2009) was used.

Considering the stress reduction in the timber portion and the maximum displacement reduction that were observed in the fiber reinforced glulam beams, the use of Vectran ${ }^{\circledR}$ fibers as reinforcement material resulted in lower mechanical gains compared to carbon fibers. On the other hand, when compared to glass fibers resulted in higher mechanical performance.

However, the same mechanical gains provided by the use of carbon fiber as reinforcement material can be reached employing a thicker layer of Vectran ${ }^{\circledR}$ fiber. Taking into account the average cost of these materials, Vectran ${ }^{\circledR}$ fiber has the advantage of costing about 2.5 times less than carbon fiber. Furthermore, Vectran ${ }^{\circledR}$ exhibits unique chemical, physical and thermal properties that the use of carbon fiber cannot be achieved. Thus, Vectran ${ }^{\circledR}$ fibers for structural reinforcement is an interesting alternative, especially for low- resistance class' wood species.

Analogously, the high mechanical gain could be achieved by the use of a thicker layer of glass fiber too. For this case, the layer of glass fiber would have to be thicker than both carbon and Vectran ${ }^{\circledR}$ fibers to achieve equivalent resistance gains. Even though, glass fiber is much cheaper than carbon fiber, the cost difference between glass and Vectran ${ }^{\circledR}$ fibers is not very significant. As glass fiber has the highest density of the materials considered in this study, the use of a thicker layer of glass fiber also resulted in the highest permanent load increase in the reinforced beam. Considering both the cost and the results of stress and displacements, the use of Vectran ${ }^{\circledR}$ fiber can be an interesting alternative when compared to glass fiber.

For all fiber material alternatives analyzed in this research, the reinforcement position affects the maximum tensile stress in the timber portion of the reinforced beam. When a typical geometry 1 configuration was assumed, the tensile stress in timber portion was higher than when a typical geometry 2 configuration was took into account. The average variation between the two geometries was $15 \%$ for Vectran ${ }^{\circledR}$ fiber reinforced timber beams and $13 \%$ for carbon fiber or glass fiber reinforced timber beams. 
Figure 10 - Maximum tensile stress in timber portion $\left(\mathrm{kN} . \mathrm{cm}^{2}\right)$ - VT-1 to VT-4F

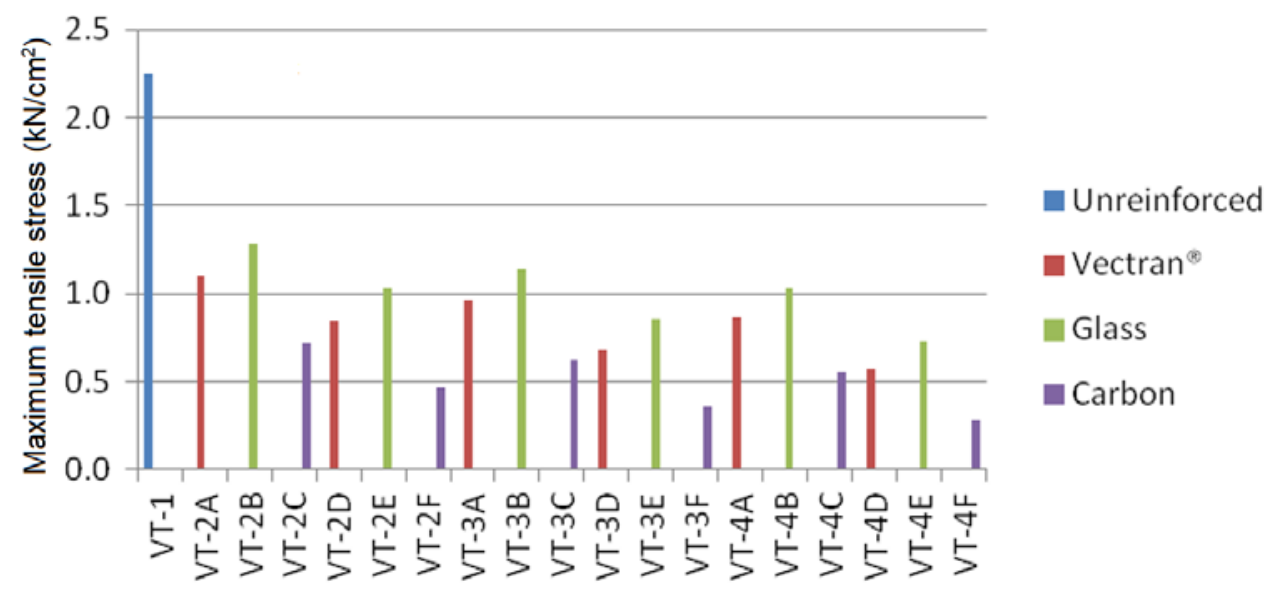

Figure 11 - Maximum tensile stress in timber portion $\left(\mathbf{k N} . \mathrm{cm}^{2}\right)$ - VT-5 to VT-8F

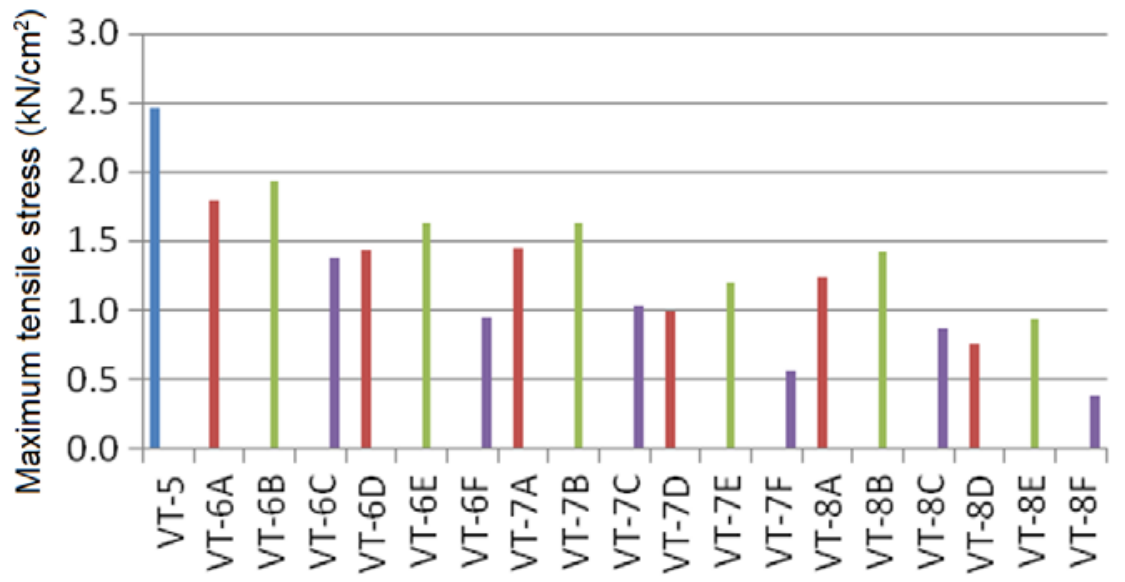

Unreinforced

- Vectran ${ }^{\odot}$

- Glass

arbon

Figure 12 - Maximum tensile stress in timber portion $\left(\mathbf{k N} . \mathrm{cm}^{2}\right)$ - VT-9 to VT-12F

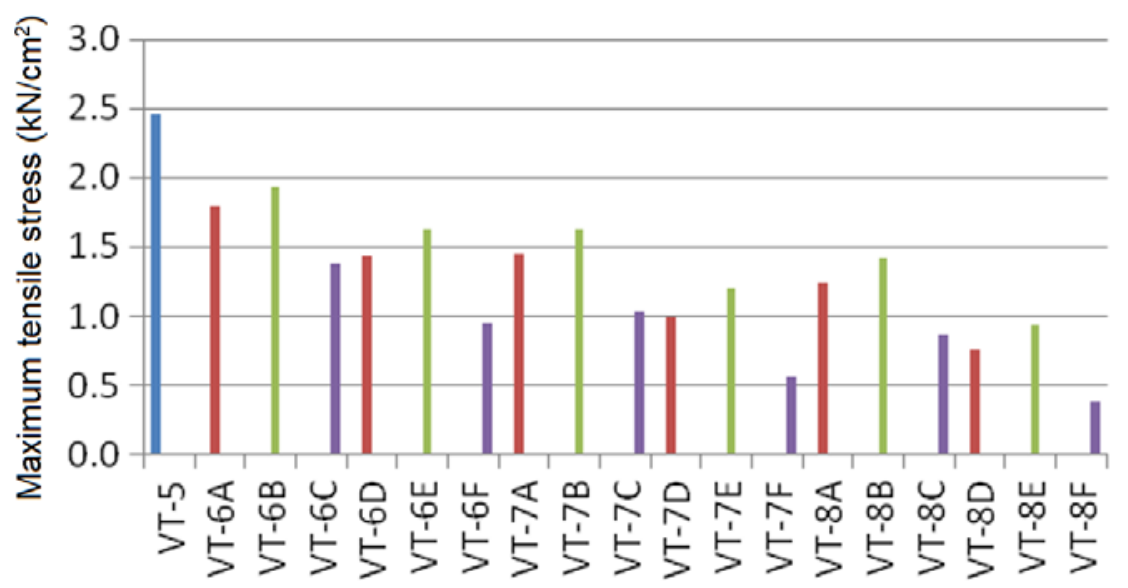

- Unreinforced

- Vectran ${ }^{\oplus}$

Glass

Carbon 
Figure 13 - Maximum displacement in the beams (cm) - VT-1 to VT-4F

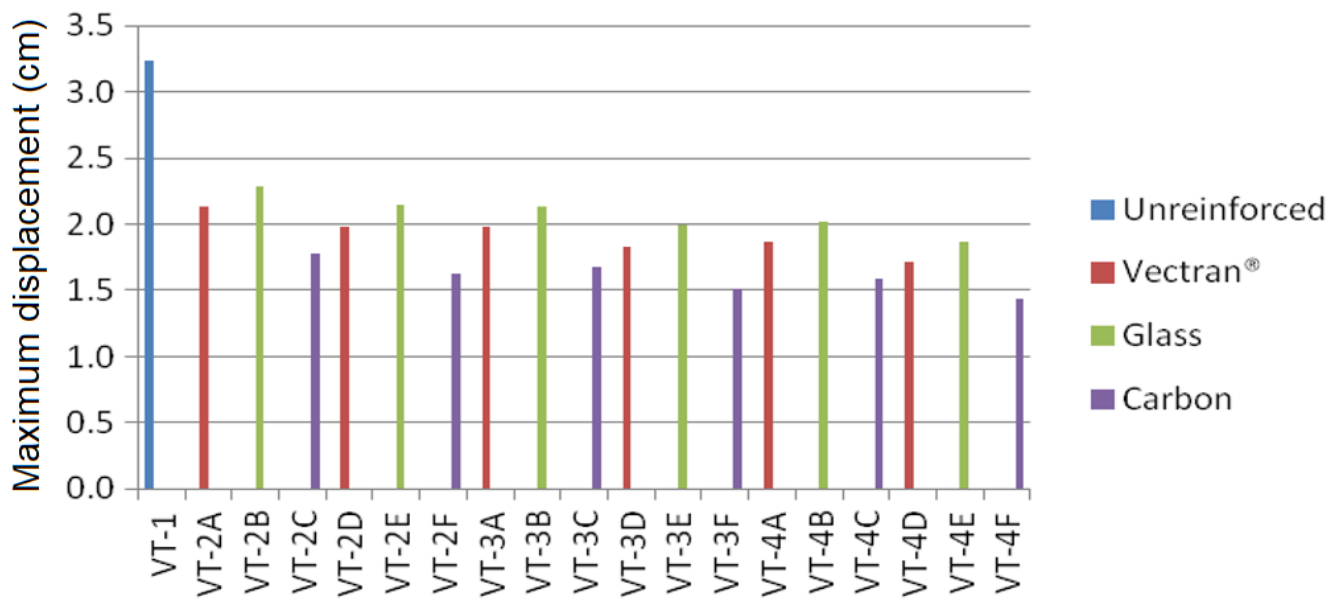

Figure 14 - Maximum displacement in the beams (cm) - VT-5 to VT-8F

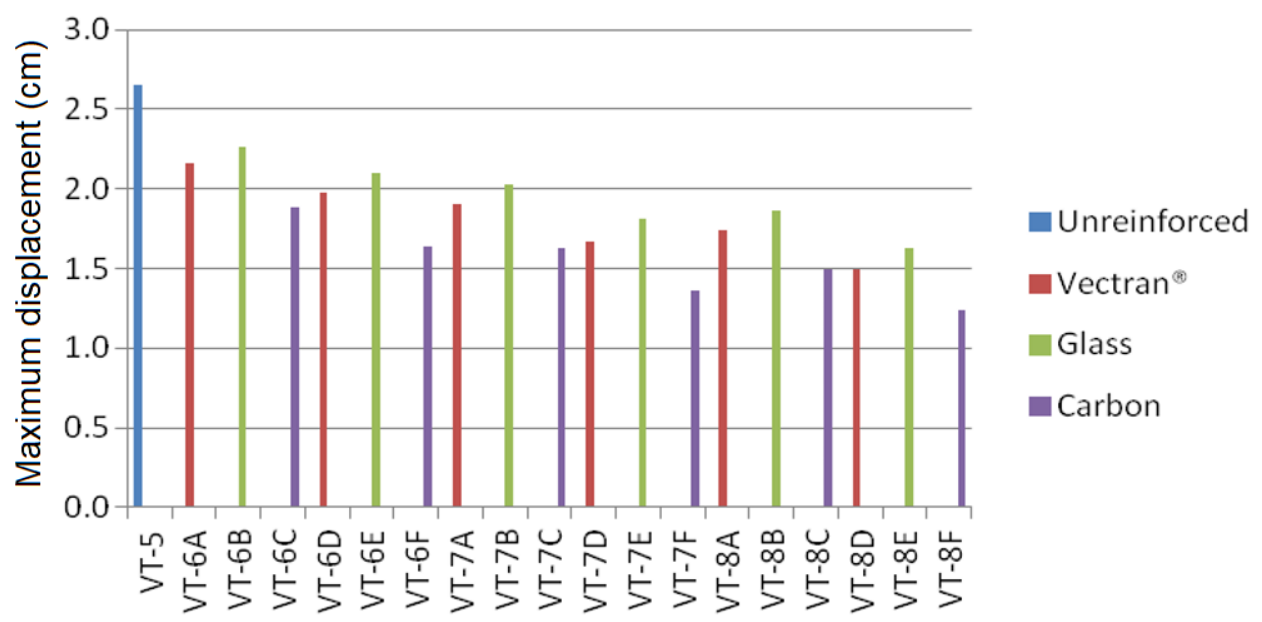

Figure 15 - Maximum displacement in the beams (cm) - VT-9 to VT-12F

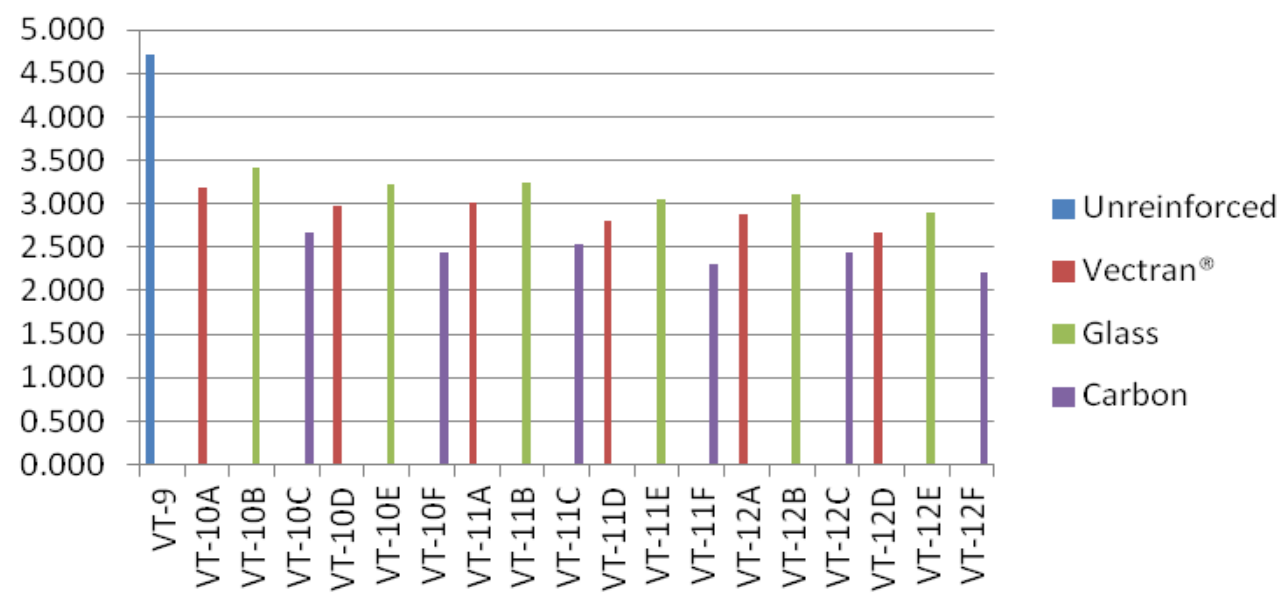

As this study covers a numerical approach, it is interesting to consider experimental procedures for future research related to the Vectran ${ }^{\circledR}$ fiber's use as structural reinforcement material.

\section{References}

ASSOCIAÇÃO BRASILEIRA DE NORMAS TÉCNICAS. NBR 7190: projeto de estruturas de madeira. Rio de Janeiro, 1997. 
BERTOLINE, C. A. A. Estudo Teórico de Vigas de Madeira Laminada Colada Reforçadas por Fibras Sintéticas. Campinas, 2015. Dissertação (Mestrado em Engenharia Civil) - Escola de Engenharia, Universidade Estadual de Campinas, Campinas, 2015

BERTOLINE, C. A. A. et al. Analysis of Fiber Reinforced Laminated Timber Beams. Key Engineering Materials, v. 668, p. 100-109, 2015.

BODIG, J.; JAYNE, B. A. Mechanics of Wood and Wood Composites. New York: Van Nostrand, 1982.

CUNHA, J.; SOUZA JUNIOR, D. A. Avaliação Estrutural de Peças de Madeira Reforçadas Por Fibras de Carbono. Revista Engenharia Civil, v. 20, p. 71-81, 2004.

DAGHER, H. J. FRP - Reinforced Wood in Bridge Applications. In: RILEM SYMPOSIUM TIMBER ENGINEERING, Stockholm, 1999.

Proceedings.... Stockholm, 1999.

FIORELLI, J.; DIAS, A. A. Glulam Beams Reinforced With FRP Externally-Bonded: theoretical and experimental evaluation. Materials and Structures, v. 44, p. 1431-1440, 2011.

GARCÍA, P. de la R.; ESCAMILLA, A. C.; GARCÍA, M. N. G. Bending Reinforcement of Timber Beams With Composite Carbon Fiber and Basalt Fiber Materials. Composites: Part B-Eng., v. 55, p. 528-536, 2013.

JONES, R. M. Mechanics of Composite Materials. $2^{\text {nd }}$. ed. London: Taylor \& Francis. 1999.

KURARAY AMERICAN, INC. Vectran ${ }^{\circledR}$ : Grasp the world of tomorrow - liquid crystal technology. Vectran ${ }^{\circledR}$ informational flyer. Fort Mill. 2010.

MASCIA, N. T.; MAYER, R. M.; MORAES, R. W. Analysis of Wood Laminated Beams Reinforced with Sisal Fibres. Key Engineering Materials, v. 600, p. 97-104, 2014.

NEUBAUEROVÁ, P. Timber Beams Strengthened by Carbon-Fiber Reinforced Lamellas. Elsevier. 2012. Procedia Engineering 40.
PIZZO, B.; SMEDLEY, D. Adhesives For On-Site Bonding: characteristics, testing and prospects. Construction and Building Materials, v. 97, p. 67-77, 2015.

RAFTERY G. M.; RODD, P. D. FRP

Reinforcement of Low-Grade Glulam Timber Bonded With Wood Adhesive. Construction and Building Materials, v. 91, p. 116-125, 2015.

ROMANI, M.; BLAß, H. J. Design Model for FRP Reinforced Glulam Beams. In: INTERNATIONAL COUNCIL FOR RESEARCH AND INNOVATION IN BUILDING AND CONSTRUCTION, Venice, 2001. Proceedings... Venice, 2001.

SCHOBER, K-U. et al. FRP Reinforcement of Timber Structures. Construction and Building Materials, v. 97, p. 106-118, 2015.

SILVA, R. V.; AQUINO, E. M. F. Curauá Fiber: a new alternative to polymeric composites. Journal of Reinforced Plastics and Composites, v. 27. n. 1, p. 103-12, 2008.

SWANSON ANALYSIS SYSTEMS INC. Ansys Reference Manual Version 12. 2009.

THELANDERSSON, S.; LARSEN, H. J. Timber Engineering. New Jersey: Wiley, 2003.

TSALKATIDIS, T. Numerical Simulation and Analytical Study of Glulam Timber Beams. International Journal of Engineering \& Technology, v. 3, n. 2, p. 129-136, 2014.

WOOD HANDBOOK. Wood as an Engineering Material. General Technical Report FPL-GTR190. Madison, WI, U.S. Department of Agriculture. Forest Service. Forest Products Laboratory. 2010.

ZIENKIEWICZ, O. C.; TAYLOR, R. L. The Finite Element Method. $5^{\text {th }}$ ed. Oxford: Butterworth-Heinemann, 2000.

\section{Acknowledgement}

The authors thank CNPq - Conselho Nacional de Desenvolvimento Científico e Tecnológico for financial support and Kuraray Company for the information and supply of Vectran ${ }^{\circledR}$ fibers. 


\section{Nilson Tadeu Mascia}

Faculdade de Engenharia Civil, Arquitetura e Urbanismo | Universidade Estadual de Campinas | Av. Saturnino de Brito, 224, Cidade Universitária | Campinas - SP - Brasil | CEP 13083-889 | Caixa Postal 6143| Tel.: (19) 3521-2302 | E-mail: nilson@fec.unicamp.br

\section{Carlos Augusto Abade Bertoline}

Faculdade de Engenharia Civil, Arquitetura e Urbanismo | Universidade Estadual de Campinas | E-mail: carlos_bertoline@hotmail.com

\section{Cilmar Donizeti Baságlia}

Faculdade de Engenharia Civil, Arquitetura e Urbanismo | Universidade Estadual de Campinas | E-mail: cbasaglia@fec.unicamp.br

\section{Bruno Fazendeiro Donadon}

Faculdade de Engenharia Civil, Arquitetura e Urbanismo | Universidade Estadual de Campinas | E-mail: donadon.bf@gmail.com

\section{Revista Ambiente Construído}

Associação Nacional de Tecnologia do Ambiente Construído

Av. Osvaldo Aranha, 99 - 3o andar, Centro

Porto Alegre - RS - Brasil

CEP 90035-190

Telefone: +55 (51) 3308-4084

Fax: +55 (51) 3308-4054

www. seer. ufrgs. br/ ambienteconstruido

E-mail: ambienteconstruido@ufrgs.br 